\title{
Penambahan Kuasa Membeli dalam Pembiayaan Murabahah pada Praktik Bank Syariah
}

\author{
Jalaluddin FA \\ Universitas muhammadiyah Yogyakarta \\ Correspondence email: jalaluddin2fa@gmail.com
}

\begin{abstract}
Abstrak. Salah satu produk dari bank syariah yang merupakan hasil modivikasi adalah akad pembiayaan murabahah. Yaitu, transaksi jual beli dimana pihak perbnakan menyebut jumlah keuntungannya. Pihak perbankan bertindak sebagai penjual, sementara nasabah bertindak sebagai pembeli. Dalam pembiayaan muarabahah dikenal istilah murabahah dengan kuasa membeli. Pelaksanaan pembiayaan murababahah dengan kuasa membeli adalah, ketika nasabah mengajukan pembiayaan murabahah di bank syariah, nasabah tidak hanya melaksanakan kontrak pembiayaan murabahah melainkan nasabah juga diberikan suatu kuasa dari pihak bank untuk membeli secara langsung barang yang ingin dibeli. Penelitian ini ingin mengetahui apakah pelaksanaan pembiayaan murabahah dengan kuasa membeli sesuai dengan syariat Islam atau tidak. Pada penelitian ini menggunakan salah satu jenis penelitian yaitu penelitian yang berbentuk penelitian yuridis normatif. Peneliti menganalisa data menggunakan teknik penelitian deskriptif. Penelitian ini menghasilkan bahwa pembiayaan murabahah dengan kuasa membeli dibolehkan dalam syariat Islam dengan syarat perlu kehati- hatian dalam melaksanakan kedua akad tersebut. Tidak boleh dilaksanakan secara bersamaan, harus diperjelas status kepemilikannya dan penambahan harga harus disepakati diawal akad.
\end{abstract}

Kata Kunci : Syariat Islam, Muarabahah, Kuasa Membeli, Perbankan Syariah

\begin{abstract}
Abctract. One of the sharia bank products which is the result of modification is a murabahah financing contract. Namely, buying and selling transactions where the bank mentions amount of profits. The bank as a seller, while the customer as a buyer. In muarabahah, there is a contract known as murabahah with buying authority. The implementation of murababahah with buying authority is, when a customer proposes murabahah financing in Islamic bank, the customer does not only carry out the murabahah financing contract but the customer is also given an authority from the bank to buy the goods desired directly. This study wants to find out whether the implementation of murabahah financing with buying authority allows in Islamic law or not. This research uses normative juridical research type. Researcher analyzes data using descriptive research techniques. This research results that murabahah financing with buying authority is allowed in Islamic law with the condition that in carrying out two contracts is needed to conduct carefully. It must not be conducted in same time, the ownership status must be clarified and the price must be agreed at the beginning of the contract.
\end{abstract}

Keywords: Islamic Law, Muarabahah, Buying Authority, Sharia Banking

\section{PENDAHULUAN}

Perkembangan bank syariah di Indonesia terhitung sangat cepat dan merata, akan tetapi meskipun sudah menyebar keseluruh daerah khususya di kota- kota besar masih banyak yang belum faham tentang konsep yang ditawarkan oleh bank syariah. Banyak diantara kita yang mengirah bahwa pelabelan bank syariah hanya sebagai strategi untuk menarik nasabah dengan memanfaatkan kondisi masyarakat kita di Indonesia yang mayoritas muslim. Contonya, kontrak yang diawali dengan kalimat bismillahirrahmanirrahim, pegawainya yang diwajibkan menggunakan busana muslim atau menggunakan ucapan assalamualaiikum untuk membuka interaksi dengan nasabah. Serta kritikan- kritikan yang mengarah kepada pernyataan bahwa akad yang dipratikkan pada bank syariah di Indoneisa belum menerapkan prinsip yang sejalan dengan apa yang disyariat dalam agama Islam secara penuh.

Tantangan besar yang dihadapi oleh bank syariah dalam pengembangannya adalah harus bersaing dengan bank konvesional dengan tawaran- tawaran produk menarik yang tidak bisa diadopsi secara langsung oleh bank syariah. Alasannya adalah terdapat beberapa produk bank konvensional yang tidak sesuai dengan yang seharusnya diterapkan dalam syariat Islam, sedangkan dalam bank syariah jika terdapat klausa yang bertentangan dengan syariat Islam maka akad tersebut dinyatakan batal. larangan yang paling sering menjadi topik utama dalam transaksi perbankan konvensional adalah adanya beberapa produk yang mengandung riba, maisir dan gharar. ${ }^{1}$

Dengan alasan tersebut diatas, menginisiasi bank syariah untuk berinovasi demi menghasilkan produk dengan tujuan akhir yang sama namun dengan akad yang berbeda dengan tidak melanggar prinsip syariah.

Salah satu dari produk bank syariah yang merupakan hasil inovasi ataupun modivikasi adalah akad pembiayaan murabahah. Yaitu, transaksi jual beli barang dimana pihak bank menyebutkan jumlah keuntungan yang diperoleh. Dalam hal ini bank bertindak sebagai yang menjual barang, sementara nasabah bertindak sebagai pembeli dari barang

${ }^{1}$ Muhammad Nurul Alim ,Tinjauan Fikih Muamalah Atas Produk Jasa Berbasis Ujrah (Fee Based Services) Bank Konvensional (Sampel Produk Bank Mandiri Dan Bca) Jurnal Asy- Syukriyyah Vol. 19 Nomor 2 Oktober 2018, Hlm. 147 
yang dimaksud. Kedua belah pihak harus membuat kesepakatan mengenai harga jual maupun jangka waktu pembayarannya saat terjadi akad. Termasuk harga jual juga dicantumkan dalam akad tersebut dan jika telah terjadi kesepakatan diantara keduanya mengenai akad tersebut, maka tidak dapat diubah selama berlakunya akad ,sementara pembayaran dilakukan secara tangguh atau secara berangsur. ${ }^{2}$

Pembiayaan murabahah dikatakan sebagai hasil modivikasi karena adanya ketidak samaan konsep antara konsep pembiayaan murabahah dalam praktik bank dengan konsep syariah dengan konsep murabahah dalam fikih. Pembiayaan murabahah yang dilaksanakan dalam bank syariah terdapat dua jenis, yaitu murabahah dengan pesanan membeli dan murabahah dengan kuasa membeli. Khusus untuk pembiayaan murabahah dengan pemberian kuasa untuk membeli barang tidak melakasanakan pembiayaan murabahah secara murni seperti yang sering dijelaskan dalam konsep fikih, melainkan terdapat dua teransaksi yang berbeda yang dijalankan secara bersama- sama yaitu, akad pembiayaan murabahah dan akad pemberian kuasa untuk membeli barang.

Pelaksanaan pembiayaan murababahah dengan kuasa membeli adalah, ketika nasabah mengajukan pembiayaan murabahah bank syariah, nasabah tidak hanya melaksanakan kontrak pembiayaan murabahah melainkan nasabah juga diberikan kuasa dari pihak bank untuk membeli secara langsung barang yang menjadi keinginan nasabah.

Sesuai dengan pelaksanaan tersebut diatas pihak bank perlu berhati- hati, karena pembiayaan murabahah yang diperaktikkan tersebut berpotensi menyalahi hadits yang diriwayatkan oleh Ahmad dan an-Nasa-i dari Abu Hurairah Radhiyallahu anhu. "Bahwa Nabi Shallallahu 'alaihi wa sallam melarang melakukan dua transaksi dalam satu transaksi jual beli." (Hadits ini dishahihkan oleh at-Tirmidzi dan Ibnu Hibban). Selain itu transaksi tersebut, berpotensi adanya ketidak jelasan (gharar) tentang status kepemilikan barang yang diperjual belikan saat terjadinya transaksi, selanjutnya juga berpotensi adanya penambahan harga yang diharamkan (riba), karena adanya penanguhan pembayaran oleh nasabah.

\section{Rumusan Masalah}

Berdasarkan latar belakang yang tertera diatas, maka yang menjadi pokok permasalahan yang timbul dalam penelitian ini adalah apakah akad pembiayaan murabahah yang dipraktikkan dalam bank syariah bertentangan dengan perinsip syariah atau tidak?

\section{METODE PENELITIAN}

Penelitian ini merupakan penelitian hukum normatif yaitu suatu penelitian yang mengkaji hukum dari persfektif internal yang objeknya adalah norma- norma hukum. ${ }^{3}$ Penlitian hukum normatif dilakukan dengan tujuan supaya mengahasilkan suatu argumentasi, konsep dan teori untuk menyelesaikan masalah- masalah baru yang timbul. ${ }^{4}$ Yang akan dikaji dalam penelitian ini adalah mengenai kesesuain hukum syariah dengan akad pembiayaan murabahah pada peraktik bank syariah. Penelitian ini mengunakan metode pendekatan perundang- undangan yang dalam hal ini tidak terlalu fokus pada perundang- undangan hukum positif, akan tetapi lebih kepada produk hukum mengis1kat yang berkaitan dengan hukum syariah.

Peneliti menggunakan bahan hukum primer yang terdiri dari Al-Qur'an, Hadis, Fatwa DSN-MUI maupun Peraturan perundang-undangan yang terkait dengan masalah yang dikaji, selanjutnya peneliti menggunakan bahan hukum sekunder yang terdiri dari bahan hukum yang diperoleh dari buku- buku dan jurnal ilmiah yang berkaitan dengan permasalahan yang dibahas. Peneliti juga menggunakan bahan hukum tersier yang diperoleh dari bahan hukum yang menjadi pelengkap dari bahan hukum primer dan bahan hukum sekunder. Selanjutnya, peneliti menganalisa data dengan menggunakan teknik penelitian deskriptif. Yaitu salah satu teknik penelitian yang digunakan dengan cara mendeskripsikan data yang telah terkumpul, setelah semua terkumpul, data-data tersebut selanjutnya dianalisa dengan cara membandingkan kenyataan yang terjadi di bank syariah khusus yang berkaitan dengan pembiayaan murabahah dengan kuasa membeli dengan teori yang sudah dipelajari dan hasil analisa tersebut ditarik dalam suatu kesimpulan.

\section{HASIL DAN PEMBAHASAN \\ Pembiayaan Murabahah}

Sabagai salah satu dari bagian fiqih maliyyah murabahah merupakan suatu penjualan dengan pembalian dan keuntungan yang suda diketahui bersama. ${ }^{5}$ Dari bahasa asal kata murabahah berasal dari kata yang berbahasa arab yaitu rabiha yarbahu- ribhan- warabahan yang mempunyai arti memberikan keuntungan, kemudian mengalami perubahan

\footnotetext{
${ }^{2}$ Daeng Naja, Akad Bank Syari'ah, (Yogyakarta: Pustaka Yustisia, 2011),Hlm.43

${ }^{3}$ I Made Pasek Diantha, Metode Penelitian Hukum Normatif Dalam Justifikasi Teori Hukum, ( Jakarta: Prenada Media Group, 2019), Hlm. 12

${ }^{4}$ Peter Muhammad Marzuki. Penelitian Hukum. Jakarta: Kencana, 2005, Hlm. 35.

${ }^{5}$ Sayyid Sabiq Fikih Sunnah, Terjemahan, Jilid 12, (Alih Bahasa: Kamaluddin), Bandung: Pt. Al- Ma'arif, 1988, Hlm. 82.
} 
struktur kata menjadi murabahah yang merupakan bentuk masdhar dengan arti memberikan keuntungan atas jasa penjualan barang dari si pemilik barang. ${ }^{6}$

Dalam makna terminologi murabahah merupakan aktifitas antara sesama manusia dalam mengelolah wasilah al hayah supaya menghasilkan keuntungan bersama demi kemakmuran dan kesejahteraan bersama. Ibnu Rusyd berpendapat bahwa murabahah merupakan jual beli suatu barang dengan mendapatkan tambahan dari harga asalnya untuk kemudian dijadikan sebagai keuntungan dari tambahan tersebut dengan syarat telah disepakati bersama. ${ }^{7}$

Dalam Peraturan Bank Indonesia (PBI) Nomor 10/16/PBI/2008 tentang Pelaksanaan Prinsip Syariah dalam Kegiatan Penghimpunan Dana dan Penyaluran Dana Serta Pelayanan Jasa Bank Syariah dijelaskan bahwa Murabahah merupakan suatu jual beli barang dengan besar penjualan dari harga pokok barang yang di maksud dan ditambah dengan keuntungan yang disepakati. Dalam Undang- Undang Nomor 21 Tahun 2008 tentang Perbankan Syariah di Pasal 19 ayat (1) huruf d dijelaskan bahwa akad murabahah adalah akad pembiayaan suatu barang dengan menegaskan harga belinya kepada pembeli dan pembeli membayarnya dengan harga yang lebih sebagai keuntungan yang disepakati. Dalam Fatwa DSN Nomor 04/DSNMUI/IV/2000 tentang Murabahah juga dijelaskan bahwa pengertian Murabahah adalah menjual suatu barang dengan menegaskan harga belinya kepada pembeli dan pembeli membayarnya dengan harga yang lebih sebagai laba.

Terkait dengan persoalan murabahah Rasulullah pernah bersabda dalam satu hadits dari Shuaib r.a bahwa Rasulillah SAW bersabda "tiga hal yang didalamnya terdapat keberkahan, jual beli secara tangguh( murabahah), muqaradah (mudharabah), dan mencampur gandum dengan tepung untuk kepentingn rumah bukan untuk diperjualbelikan. ( HR Ibnu Majah) ${ }^{8}$.

Hadits diatas menjelaskan bahwa rasullah membolekan murabahah. Bahkan jika murabahah dikelolah dengan sebaik mungkin dengan tetap memperhatikan nilai kejujuran dan keadilan serta prinsip- prinsip transaksi yang dianjurkan dalam Islam maka dengan melaksanakan transaksi murabahah akan mendatangkan keberkahan. Keberkahan yang dimaksud adalah akan lahir suatu kerjasama dalam pengelolahan modal awal sehingga bisa memberikan peluang untuk medapatkan keuntungan yang lebih dan kemudian akan memberikan kesejahteraan kepada sesama manusia.

Dalam murabahah mengenai rukun yang harus terpenuhi adalah sebagai berikut: ${ }^{9}$

1. Pihak yang berakad

a. Cakap menurut hukum

b. Tidak terpaksa

2. Barang/objek

a. Barang tidak terlarang oleh syara'

b. Penyerahan barang dapat dilakukan

c. Hak milik penuh yang berakad

3. Harga

a. Memberitahukan harga pokok

b. Keuntungan yang telah disepakati

4. Ijab Kabul atau sighat
a. Harus jelas
b. Harga dan barang yang disebutkan harus seimbang
c. Tidak dibatasi oleh waktu

Adapun syarat yang harus terpenuhi adalah sebagai berikut: ${ }^{10}$

1. Penjual barang harus memberikan transfaransi mengenai harga pokok kepada pihak yang akan membeli barang;

2. Kontrak harus sah sesuai dengan rukun jual beli yang telah ditetapkan;

3. Kontrak yang dilaksanakan tidak boleh mengandung riba;

4. Penjual tidak boleh menyembunyikan jika terjadi cacat atas barang yang dijual sesudah pembelian;

5. Jika terdapat hal- hal lain mengenai pembelian, misalnya adanya hutang saat pembelian maka, penjual wajib menjelaskannya.

Dalam Fatwa DSN Nomor 04/DSNMUI/IV/2000 terdapat beberapa janji yang harus dipatuhi: ${ }^{11}$

1. Nasabah mengajukan janji permohonan dan janji untuk membeli suatu barang atau asset kepada bank.

286

${ }^{6}$ M. Hasbi Umar, Filsafat Fiqih Muamalat Kontemporer Filosofi Dasar Untuk Aksi, Jakarta: Pt Rajagrafindo Persada, Hlm.

${ }^{7}$ Ibid.

${ }^{8}$ Ibnu Majah, Sunan Ibnu Majah Dalam Kitab Al- Tijarah, Juz 2, Ttp., Hlm. 786.

${ }^{9}$ Zulkifli, Sunarto, 2003, Panduan Praktis Transaksi Perbankan Syariah, Jakarta, Zikrul Hakim. HIm 40

${ }^{10}$ Antonio, Muhammad Syafi'i, 2001, Bank Syariah Dari Teori Ke Praktik, Jakarta, Gema Insani. Hlm. 102

${ }^{11}$ Jaih Mubarak Dan Hasanuddin Fikih Muamalah Maliyyah; Prinsip- Prinsip Perjanjian, Jakarta: Simbiosa Rekatama Media, 2017, Hlm. 19 
2. Jika bank menerima permohonn tersebut, ia harus membeli terlebih dahulu asset yang di pesannya secara sah dengan pedagang.

3. Bank kemudian menawarkan asset tersebut kepada nasabah dan nasabah harus membelinya sesui dengn janji yang telah di sepakatinya karena secra hukum janji tersebut mengikat; kemudian kedua belah pihak harus membuat kontrak jual beli.

4. Dalam jual beli ini, bank diperbolehkan meminta nasabah untuk membayar uang mukasaat menandatangani kesepakatan awal pemesanan.

5. Jika nasabah kemudian menolak membeli barang tersebut, biaya nyata bank harus dibayar dari uang mmuka tersebut.

6. Jika nilai uang muka kurang dari kerugian yang harus ditanggung oleh bank, bank dapat meminta kembali sisa kerugian kepada nasabah.

7. Jika uang muka memakai kontrak 'urbun' sebagai alternative dari uang muka maka:

a. Jika nasabah memutuskan untuk membeli barang tersebut ia tinggal membayar sisa harga.

b. Jika nasabah batal membeli, uang muka menjadi milik bank maksimal sebesar kerugian yang ditanggung oleh bank akibat pembatalan tersebut; dan jika uang muka tidak mencukupi, nasabah wajib melunasi kekurangnnya.

\section{Kuasa Membeli}

Kuasa membeli adalah salah satu akad yang sering dikaitkan pelaksanaannya dalam pembiayaan murabahah yang menjadi salah satu produk unggul di bank syariah. Akad tersebut merupakan akad antara pihak bank dengan nasabahnya yang memilih untuk mengajukan suatu pembiayaan yaitu pembiayaan murabahah ke bank syariah. Dalam hal ini bank sebagai pemberi kuasa dan nasabah sebagai pelaksana dari kuasa yang diberikan bank untuk membeli barang ke suppler dimana barang tersebut tidak lain adalah barang yang diajukan oleh nasabah itu sendiri. Dalam ilmu fikih pemberian kuasa untuk membeli barang termasuk dalam bab wakalah yang berarti akad dimana seseorang menyerahkan suatu tugas kepada orang lain yang tidak bertentangan dengan syariat untuk digantikan mengerjakan tugas tersebut selama yang memberi tugas masih hidup. ${ }^{12}$

Dalam arti bahasa wakalah berasal dari arti bahasa arab yaitu wakalah yang merupakan sinonim dari: salama wa fawadha, yang berarti : menyerahkan. Dalam penjelasan lain Wakalah juga diartikan sebagai al-hifzhu, yang berarti : memelihara atau menjaga. Menurut istilah Syafi'iyah didefinisikan bahwa wakalah merupakan suatu "penyerahan oleh seseorang kepada orang lain terhadap sesuatu yang ia berhak mengerjakannya dan sesuatu itu bisa digantikan, untuk dikerjakannya pada masa hidupnya". ${ }^{13}$

Dari penjelasan diatas dapat ditarik kesumpulan bahwa wakalah merupakan penyerahan tugas dari pihak pertama ke pihak kedua untuk melaksanakan suatu pekerjaan yang bisa digantikan oleh orang lain dimasa hidupnya dan telah disepakati bersama. Dan jika penyerahan tersebut harus dilakukan setelah meninggal dunia seperti wasiat maka hal tersebut tidak bisa disebut sebagai wakalah.

Dalam Kompilasi Hukum Ekonomi Syariah (KHES) dalam Buku II, Bab I, pasal 20 ayat 19 dijelaskan bahwa wakalah adalah pemberian kuasa kepada pihak lain untuk mengerjakan sesuatu. Dalam KUHPerdata juga dijelaskan dalam Buku III, Bab VIII pasal 1792 bahwa pemberi kuasa ialah suatu persetujuan yang berisikan pemberian kekuasaan kepada orang lain yang menerimanya untuk melaksanakan sesuatu atas nama orang yang memberi kuasa.

Semua imam mazhab membolehkan wakalah selama syarat dan rukun terpenuhi. Namun tidak semua hal boleh diwakilkan. Hal- hal yang boleh diwakilkan adalah yang sifatnya bisa dikerjakan oleh orang lain, seperti jual-beli, pembayaran utang, persewaan, menikahkan anak gadisnya atau menyuruh seseorang untuk menuntut hak. Sedangkan hal- hal yang sifatnya ibadah badaniyah seperti sholat atau puasa tidak boleh diwakilkan.

Salah satu dalil Al- Quran yang menjadi landasan keabsahan wakalah adalah Al- Quran surah An-Nisa ayat 35:

"Dan jika kamu khawatirkan ada persengketaan antara keduanya, Maka kirimlah seorang hakam dari keluarga laki-laki dan seorang hakam dari keluarga perempuan. jika kedua orang hakam itu bermaksud Mengadakan perbaikan, niscaya Allah memberi taufik kepada suami isteri itu. Sesungguhnya Allah Maha mengetahui lagi Maha Mengenal"

Selain dari penjelasan diatas Rasulullah SAW juga bersabdadalam salah astu haditsnya "Dari Jabir r.a ia berkata: aku pergi ke Khaibar lalu aku datang kepada Rasulullah SAW Maka beliau bersabda: bila engkau datang pada wakilku, maka ambillah dari nya 15 wasaq (HR. Abu Daud)"

Dalil- dalil diatas cukup memberikan penegasan bahwa tidak ada keraguan mengenai bolehnya melaksanakan wakalah selama dalam pelaksanaannya masih dalam koridor yang dibolehkan dan sesuai dengan rukun dan syarat wakalah yang dijelaskan dalam ilmu fikih.

\footnotetext{
${ }^{12}$ Ismail Nawawi, Fiqih Muamalah Klasik Dan Kontemporer, (Bogor: Ghalia Indonesia, 2012), Hlm. 21.

${ }^{13}$ Ahmad Wardi Muslich, Fiqih Muamalah, (Jakarta: Amzah,2013), Hlm. 418-419
} 


\section{Analisis Tentang Penggabungan Kuasa Membeli Dalam Pembiayaan Murabahah}

Pembiayaan Murabahah adalah pembiayaan dimana pihak bank bertindak sebagai penyedia dana untuk membeli barang sesuai dengan yang dibutuhkan nasabah. Praktik ini secara operasional merupakan jual-beli barang dimana bank bertindak sebagai penjual dan nasabah bertindak sebagai pembeli dengan harga perolehan atau harga jual (harga beli) ditambah dengan keuntungan (margin) yang disepakati. Dalam akad jual beli ini bank harus memberitahukan kepada nasabah mengenai harga beli dan keuntungan yang diperoleh pihak bank. Sedangkan keuntungan yang diperoleh tentu tidak melanggar prinsip kepatutan dalam mendapatkan keuntungan. Yang membedakan antara pembiayaan murabahah yang dilaksanakan di bank syariah dengan jual beli pada umumnya yakni pada pembayaran sejumlah harga beli dalam pembiayaan murabahah oleh nasabah secara umum dilakukan ditangguhkan menurut batas waktu yang disepakati.

Saat ini pelaksanaan pembiayaan murabahah di bank syariah tidak mutlak melaksanakan akad murabahah seperti yang dijelaskan dalam ilmu fikih pada umumnya. Melainkan telah mengalami modifikasi, yakni akad murabahah yang diperaktikkan di bank syariah digandengkan dengan pemberian kuasa dan janji, atau dalam istilah dalam bahasa arab disebut sebagai 'aqd al-murabahah li al-amir bi al-syira' yang secara harfiah berarti akad suatu murabahah yang disertai dengan adanya perintah untuk membeli barang. ${ }^{14}$

Akad murabahah dengan kuasa membeli merupakan salah satu transaksi yang diperaktikkan dalam bank syariah, yang dilaksanakan dengan mejalankan dua akad sekaligus, yakni adanya akad murabahah dan juga akad wakalah. Sehingga secara tidak langsung taransaksi tersebut, memang bertentangan dengan hadits yang diriwayatkan oleh Ahmad dan an-Nasa-i dari Abu Hurairah Radhiyallahu anhu. "Bahwa Nabi Shallallahu 'alaihi wa sallam melarang melakukan dua transaksi dalam satu transaksi jual beli." (Hadits ini dishahihkan oleh at-Tirmidzi dan Ibnu Hibban). Selain itu juga terlihat adanya ketidakjelasan mengenai status kepemilikan dari barang yang diperjual belikan. Karena ketika kepemilikan barang berpindah saat nasabah membeli barang di supplier maka status uang bank yang digunakan nasabah saat membeli barang adalah hutang, dan bank tidak boleh mengambil keuntungan dari hutang tersebut. Dalam Hadits yang diriwayatkan oleh Al-Harits Ibnu Abi Usamah di jelaskan bahwa : "Setiap utang piutang yang di dalamnya ada keuntungan, maka itu dihukumi haram ",15

Berkenaan dengan adanya anggapan tentang transaksi pelaksanaan dua akad secara bersamaan dalam satu jual beli serta keraguan dalam status kepemilikan seperti yang dijelaskan diatas. Sebenarnya dalam praktiknya, pada saat nasabah mengajukan pembiayaan murabahah dengan kuasa membeli kepada pihak bank untuk membeli barang yang diinginkan. Kerana dalam transaksi ini terdapat dua akad yang dijalankan. Untuk menghindari adanya perlanggaran dalam syariat Islam, maka kedua akad tersebut tidak sertamerta dijalankan secara bersamaan. Pertama, Pihak bank memberi kuasa kepada nasabahnya untuk membeli barang yang dikehendaki langsung ke supplier. Perlu ditekankan bahwa, ketika nasabah membeli barang ke supplier, kedudukan nasabah buakanlah sebagai calon pemilik langsung dari barang yang akan dibeli tersebut, akan tetapi nasabah hanya berkedudukan sebagai perwakilan dari pihak bank, sedangkan pemilik sah dari barang tersebut setelah dibeli dari supplier adalah pihak bank. Pada saat inilah akad pertama yakni akad wakalah dilaksanakan, dan akad wakalah akan berakhir ketika diserahkannya bukti pembelian barang kepada pihak bank. Barang tersebut akan berpindah kepemilikannya kepada nasabah ketika nasabah membelinya dari pihak bank dengan menggunakan akad selanjutnya yakni akad murabahah, akad murabahah dilaksanakan ketika barang yang akan diperjual- belikan telah menjadi milik sah dari pihak bank. Sehingga dengan adanya anggapan bahwa pada akad pembiayaan dengan kuasa membeli terjadi dua transaksi dalam satu akad tidak benar karena keduanya diselesaikan satu persatu,. Begitu juga dengan status kepemilikan barang tersebut suda sangat jelas bahwa pada transaksi pertama (wakalah) barang yang dimaksud merupakan milik bank dan akan berpindah kepada nasabah pada transaksi yang kedua (murabahah).

Tahapan transaksi diatas sesuai dengan Fatwa Dewan Syariah Nasional Majelis Ulama Indonesia (DSN-MUI) Nomor: 04/DSN-MUI/IV/2000 tentang Murabahah Pasal 1 ayat (9):"Jika bank hendak mewakilkan kepada nasabah untuk membeli barang dari pihak ketiga, akad jual beli murabahah harus dilakukan setelah barang, secara prinsip, menjadi milik bank." Sehingga dengan demikian, status kepemilikan barang yang diperjual belikan jelas sampai berakhirnya transaksi jual beli antara bank dengan nasabah.

Mengenai syarat bolehnya melaksanakan akad murabahah setelah berakhirnya akad wakalah, dan barang telah menjadi milik sah dari pihak bank dalam akad murabahah dengan kuasa membeli, juga diatur dalam Peraturan Bank Indonesia (PBI) Nomor 07/46/PBI/2005 tentang Akad Penghimpunan Dan Penyaluran Dana Bagi Bank Yang Melaksanakan Kegiatan Usaha Berdasarkan Prinsip Syariah, penggunaan akad murabahah dengan kuasa membeli (wakalah) diatur dalam Pasal 9 ayat (1) butir d yaitu: dalam hal Bank mewakilkan kepada nasabah (wakalah) untuk membeli barang, maka akad Murabahah harus dilakukan setelah barang secara prinsip menjadi milik Bank.

${ }^{14}$ Jaih Mubarok, Dan Hasanudin, 2017, Fikih Mu'amalah Maliyyah: Akad Tabarru'( Bandung, Simbiosa Rekatama Media: 2017), 224

${ }^{15}$ Winda Afriyenis, "Perspektif Ekonomi Islam Terhadap Utang Luar Negeri Pemerintah Dalam Pembangunan Ekonomi Indonesia”, Maqdis (Jurnal Kajian Ekonomi Islam), Volume 1, No.1, Januari-Juni 2016, Hlm 8. 
Dalam kompilasi hukum ekonomi syariah juga suda dijelaskan di bagian ketujuh mengenai jual beli murabahah, pada pasal 119 bahwa " jika penjual hendak mewakilkan kepada pembeli untuk membeli barang dari pihak ketiga akad jual beli murabahah harus dilakukan setelah barang secara prinsip sudah menjadi milik bank".

Dalam Konferensi Bank Islam kedua yang diselenggarakan di Kuwait pada tahun 1403 H/1983 M juga diambil keputusan bahwa kesepakatan untuk melakukan jual beli murabahah dengan adanya tambahan perintah untuk membeli barangyang diinginkan, setelah pembeli memiliki dan menguasai barang yang dimaksud, kemudian menjualnya kepada orang yang memerintahkan untuk membelinya dengan ditambahakan keuntungan yang telah disepakati oleh keduanya adalah dibolehkan menurut syariah Islam. Namun dalam hal itu pihak bank wajib bertanggung jawab jika barang tersebut mengalami kerusakang sebelum barang diterima, selanjutnya pihak bank juga wajib bertanggungjawab atas pengembalian barang jika barang yang dimaksud terdapat cacat tersembunyi. ${ }^{16}$

Dalam hadits juga dijelaskan, salah satunya adalah hadits dari Ibnu 'Abbas, Rasulullah shallallahu 'alaihi wa sallam bersabda, "Barangsiapa yang membeli bahan makanan, maka janganlah ia menjualnya kembali hingga ia selesai menerimanya." Ibnu 'Abbas mengatakan, "Aku berpendapat bahwa segala sesuatu hukumnya sama dengan bahan makanan.” (HR. Bukhari Nomor 2136 dan Muslim Nomor 1525)

Mengenai adanya penambahan harga dalam akad murabahah dengan kuasa membeli berlaku akad jual beli pada umumnya, yakni dibolehkan dengan syarat adanya kesepakatan diantara keduanya diawal. Jual beli ini dapat disamakan dengan Bai' bi Tsaman Ajil atau Bai' Mu'ajal yaitu jual beli barang yang barangnya diserahkan segera dan pembayarannya dibayar secara angsur atau ditangguhkan. ${ }^{17}$ Hingga saat ini kedudukan tentang bolehnya melaksanakan akad murabahah dengan kuasa membeli belum diatur dalam Undang-Undang Nomor 21 Tahun 2008 tentang Perbankan Syariah, hingga masih menimbulkan kontroversi untuk bertransaksi dengan menjalankan dua akad seperti ini. Sehingga perlu diatur dalam perundang- undangan perbankan syariah, agar tidak ada keraguan untuk melaksanakan akad tersebut.

\section{SIMPULAN}

Dalam syariat Islam pembiayaan murabahah dengan kuasa membeli dibolehkan. Mengenai adanya keraguan bahwa pembiayaan murabahah melaksanakan suatu transaksi yang menjalankan dua akad dalam satu akad jual beli yang dilarang tidak dapat dibuktikan karena kedua akad yang dilaksanakan diselesaikan satu persatu. Dalam pembiayaan murabahah dengan kuasa membeli mengenai status kepemilikannya suda jelas, pada saat dilaksanakan pembelian barang ke supplier barang merupakan milik perbankan meskipun nasabah yang melaksanakan akad karena dalam hal ini terjadi akad yang pertama yakni kuasa membeli (wakalah). Di akad kedua saat melaksanakan akad murabahah baru berpindah kepemilikan kepada nasabah. Selanjutnya, untuk penambahan harga berlaku jual beli pada umumnya, di bolehkan baik secara tangguh ataupun berangsur selama ada kesepakatan diawal akad mengenai jumlah harga yang harus dilunasi oleh nasabah dan tidak boleh ada penambahan di kemudian hari.

\section{DAFTAR PUSTAKA}

Ahmad Wardi Muslich, Fiqih Muamalah, Jakarta: Amzah,2013

Antonio, Muhammad Syafi'i, 2001, Bank Syariah Dari Teori Ke Praktik, Jakarta, Gema Insani

Daeng Naja, Akad Bank Syari'ah, Yogyakarta: Pustaka Yustisia, 2011

Ibnu Majah, Sunan Ibnu Majah Dalam Kitab Al- Tijarah, Juz 2

Ismail Nawawi, Fiqih Muamalah Klasik Dan Kontemporer, Bogor: Ghalia Indonesia, 2012

Jaih Mubarak Dan Hasanuddin Fikih Muamalah Maliyyah; Prinsip- Prinsip Perjanjian, Jakarta: Simbiosa Rekatama Media, 2017

Jaih Mubarok, Dan Hasanudin, 2017, Fikih Mu'amalah Maliyyah: Akad Tabarru'( Bandung, Simbiosa Rekatama Media: 2017)

M. Hasbi Umar, Filsafat Fiqih Muamalat Kontemporer Filosofi Dasar Untuk Aksi, Jakarta: Pt Rajagrafindo Persada,

Made Pasek Diantha, Metode Penelitian Hukum Normatif Dalam Justifikasi Teori Hukum, Jakarta: Prenada Media Group, 2019

Muhammad Nurul Alim ,Tinjauan Fikih Muamalah Atas Produk Jasa Berbasis Ujrah (Fee Based Services) Bank Konvensional (Sampel Produk Bank Mandiri Dan Bca) Jurnal Asy- Syukriyyah Vol. 19 Nomor 2 Oktober 2018

Muhammad Syahrullah, Konsep Murabahah Dalam Kompilasi Hukum Ekonomi Syariah Dan Implikasinya Di Peradilan Agama, Jurnal Islamika, Vol. 1, No. 2 (2018)

Peter Muhammad Marzuki. Penelitian Hukum. Jakarta: Kencana, 2005

Sayyid Sabiq Fikih Sunnah, Terjemahan, Jilid 12, (Alih Bahasa: Kamaluddin), Bandung: Pt. Al- Ma’arif, 1988

${ }^{16}$ Muhammad Syahrullah, Konsep Murabahah Dalam Kompilasi Hukum Ekonomi Syariah Dan Implikasinya Di Peradilan Agama, Jurnal Islamika, Vol. 1, No. 2 (2018), Hlm 49

17 Yenti Afrida, Analisis Pembiayaan Murabahah Di Perbankan Syariah, Jebi (Jurnal Ekonomi Dan Bisnis Islam), Volume 1, Nomor 2, Juli-Desember 2016. Hlm 158 
Winda Afriyenis, "Perspektif Ekonomi Islam Terhadap Utang Luar Negeri Pemerintah Dalam Pembangunan Ekonomi Indonesia”, Maqdis (Jurnal Kajian Ekonomi Islam), Volume 1, No.1, Januari-Juni 2016,

Yenti Afrida, Analisis Pembiayaan Murabahah Di Perbankan Syariah, Jebi (Jurnal Ekonomi Dan Bisnis Islam), Volume 1, Nomor 2, Juli-Desember 2016

Zulkifli, Sunarto, 2003, Panduan Praktis Transaksi Perbankan Syariah, Jakarta, Zikrul Hakim 